\title{
The Online Retail Status in Lebanon
}

\author{
Dora Najjar*, Miguel Shikhani, Jad Maroun, Fouad Samaan \\ University of Balamand, El Koura North Lebanon, Lebanon. \\ * Corresponding author. Tel.: +961 3 201603; email: dora.najjar@balamand.edu.lb \\ Manuscript submitted June 13, 2017; accepted February 2, 2018. \\ doi: 10.17706/ijeeee.2018.8.3.187-192
}

\begin{abstract}
This research aims to provide evidence about the Ecommerce status, effects and challenges in Lebanon. In particularly, it explores the online shopping prominence through the retailer's point of view. For this purpose, Ecommerce status, technological needs and best practices were covered in the literature review concerning European, American and some Arab countries. In order to explain this, a case study model was chosen in order to compare the online and offline retail status in Lebanon. Using a qualitative approach, the study comprised six companies, from different sectors; all of them are multichannel companies. Semi-Structured interviews were conducted.

It was found from the interviews analysis that the online shopping in Lebanon is at its beginning stages. Companies are adopting it mainly for advertisement and product promotion more than for online sales. Moreover, the poor internet infrastructure, limited available online payments choices and poor delivery made the online success very primitive compared to other countries. The study has also enabled serious personal reflection on our preconceptions about the Lebanese companies. Firstly, we had a perception that Lebanese companies do not like to bother themselves with the online retail in absolute terms, which we found not to be true. Nonetheless, the study has provided some illustrative insights which have not before been revealed in Lebanon. Further research through a quantitative survey should be done to take the customers point of view.
\end{abstract}

Key words: Ecommerce, lebanon, multichannel.

\section{Introduction}

\subsection{General View}

The online shopping business is getting bigger each year; huge number of companies are pushing toward the online trend worldwide as technology is evolving too fast. The twentieth century is an important era where social, financial and political developments have happened; beside the globalization, elimination of borders, technological improvements and inevitable passing to the information society that has greatly influenced and reformed the present guidelines of the business world [1]. Reference [2] shows that the Internet rapidly became the main platform of communication and provided accessibility for doing business. The utilization of the internet for business determinations offered ascends to the presence of the electronic commerce (Ecommerce). Commercial Institutions implemented information and communication innovation to support their business activities which leads to the development of the electronic business concept [1]. Ecommerce can be illustrated as the buying, selling and trading of goods and services between businesses, consumers and any other parties without the need for a physical contact, all these performed through the Internet [1]. 
There are many researchers that adopted the topic of the online retail sector. It covers almost all countries worldwide especially in Europe, India and some Arab countries. Those previous research revealed strong influence of the online retail sector. This study will be conducted in Lebanon because we noticed that in Lebanon online retailing and multichannel retailing started to emerge few years ago, which make it an interesting field to study the status of the online retail in Lebanon.

\subsection{Key Research Questions}

Throughout this research the below key research questions will be answered:

1. Why the online shopping is not popular yet among retailers in Lebanon?

2. How Lebanese offline retailers are acting toward this new business trends?

\section{Ecommerce}

Ecommerce refers to the 1960 decade when it was used for transferring of governmental, military and commercial documents that was at that time a simple information system [3]. The internet and the technological advances lead to a massive growth of Ecommerce. Today's businesses have access to cost effective Ecommerce solutions due to cloud based software solutions. The financial barrier of entry to Ecommerce became less compared to brick and mortar [4].

\subsection{Types}

Ecommerce market model is split up into 4 sections in consideration with the features of the selling and buying parties [5]. These sections are: B2B (Business to Business), B2C (Business to Consumer), C2C (Consumer to Consumer), C2B (Consumer to Business). In this research paper, we will focus on the B2C (Business to Consumer) Ecommerce category through online shopping retailers in Lebanon. Reference [6] shows that a big number of retailers worldwide became multichannel due to the increase number of sales coming online. The interviewed companies are multichannel which means they exist online and offline. One of the interviewed companies company A explained the importance of being Ecommerce by saying that "social media will lead to indirect sales and we use it for advertisement for our brand". The rest five companies B, C, D, E and F answers were similar "we are integrating both functions transaction and advertisement".

\subsection{Challenges}

Reference [7] indicates that in order to improve the website services, we should enhance client's communication with the firm. One of the main communication components is the customer review section; in this case, the company can calculate the level of satisfaction of every client based on the item he chose. Company A and company E answered negatively about the customer review section but they interact with the customers via emails, it may be related to the products or services that they provide, as many items may be debatable across multiple customers. All remaining companies do have this review section that can help the customer to know other clients experience, thus will definitely rise the level of fulfilment of the client and put the company in a very transparent position.

Furthermore, all interviewed companies have 2D images on their website and do not have any initiative to introduce the 3D modeling in the near future. Comparing these websites to the international designs, we can see the lack of some features especially the 3D modeling which can help the customer to check the product from different angle. Reference [8] shows that image manipulation (customers can check the product in a 3D virtual experience tour) and entertainment are to motivate customers to buy online and be satisfied to become a repetitive customer.

A major constraint for Ecommerce success is the internet infrastructure. However, in Lebanon people 
suffer from low bandwidth and disconnections due to very bad infrastructure. The government is not investing in improving the existing old infrastructure. Fiber connectivity to industries or home is still a dream to come true in the next coming years. As noticed all the companies complained about the internet infrastructure. The majority agreed that the online business success in Lebanon starts with the availability of a fast, reliable and stable internet connection. Reference [9] shows that there are many barriers before and after entrance in the Ecommerce market, a main barrier is poor technology and internet infrastructure.

\section{Factors Influencing Consumer to Shop Online}

Reference [10] displays that "internet shopping has become the fastest-growing use of the Internet; most online consumers, however, use information gathered online to make purchases off-line." All the interviewed companies stated that their customers use their online presence for product search and off-line purchase more than for transaction purpose.

Reference [11] shows that the Ecommerce web site should have extra features to succeed and attract the consumer like: - The ability to change the site language by providing the highest number of languages. Provide the site with a good and fast search engine. - Security policies should be displayed in a clear way. Present many payment options. - Dropping the number of clicks to complete a transaction to the minimum.

There are many aspects influencing people to shop online, researchers have nominated the top four factors: types and features of products, security, website design/features, customer relationship management.

Product/service type plays a main role to encourage the consumers to buy them online. The requested product can be modified by most interviewed companies but the customer may have some ideas that cannot be delivered online, the customer in this case will have to visit the store especially if the product is a precious item like jewelry. One of the companies that buys and sells books, customization is not an option, and the price is a fix one. Same situation in the home appliance section, as the company cannot customize the product, the discount is published on the item online, so the price customization will be reflected to all online shoppers and not to a specific person, but if the client is visiting the store physically a price discount could be made.

"Safe and secured transaction of money and credit card information increases trust and decreases transaction risk" [12]. Most of the interviewed companies use SSL (secure sockets layer) used by most websites which is the typical security technology to make a secure transaction. As we were told by the sales manager of company E "Payments are done in a secure connection and we never store any credit or debit card in our database; which make the customers feel comfortable after knowing all these security procedures that lead to increase the online purchasing power". Electronic Payment Systems (EPS; e.g., credit cards, PayPal, AliPay and Google Wallet) enable payment for goods and services without the use of cash as per reference [13]. We understood from the interviews that the Central Bank in Lebanon does not permit the usage of international payment systems such as PayPal for different reasons, any online gateway used in Lebanese online shopping stores are online cards issued by local banks and managed by them and monitored by the central bank. They added that these restrictions affected Ecommerce in Lebanon from not benefiting of the features available in different countries and can hinder the improvement of the online shopping experience. They mentioned also that payment choices are the same among most Lebanese retailers; it's combined between credit/debit cards (master and visa cards) or cash on delivery.

In this research, all interviewed companies follow the old traditional culture where the company and the website are named after the owner family name. None of the names is related to the type of business they practice; which make it difficult for the customer to find the company on a search engine. On the other side for the design of the website, all the domain names are paid, so they tend to buy and register professional hosting plans in order to keep the website safe and legal. Moreover, the easiness to access the website is 
common between all companies, the first step which is called the subscription phase needs to take more time in order to get some crucial information related to the user, but once the subscription phase is completed, all customers can shop any item they want with just few clicks.

Loyalty is an essential part for a successful business, it can be achieved by meeting customers need better than competitors can do. Reference [14] indicates the way that online retailers can retain customers by proposing different programs divided into different categories: brand image, prices, product quality and service. All the studied companies are aware of the loyalty importance and huge effort took place to gain the customers' loyalty and to sustain it. One of the most effective ways to gain customers' loyalty is special prices and special discounts. Service before and after sale are becoming main elements to have a success business and to gain the customers' loyalty for all the interviewed companies.

\section{Methodology and Limitation}

Case studies can be of particular value where the researcher aims to provide practitioners with better or alternative ways of doing things. This partly accounts for the popularity of case study within management research and the whole area of managing change [15]. Case study strategy should be according to the kind of enquiries in the research questions. It could be an exploratory, descriptive or explanatory case study [16]. The online retail trend is a new topic in the Lebanese market. There are little or no research data to date through secondary research. Secondary research is a research that was done previously under the same concept by someone else who collects the needed data and analyses it [17]. An exploratory research is the proper investigation to discover ideas and insights for a problem [18]. Our case studies had elements of exploration. We wanted to know: what is the status of online shopping among retailers in Lebanon, how Lebanese offline retailers are adapting to this new business trend, and what should be done to be on the top of the line.

Exploratory research can be conducted in three main ways: A search of literature, Focus group interviews, interviewing experts in the subject.

In this paper, the third way of exploratory research is used to help in determining the best research design, data-collection method and selection of subjects.

Primary data collection can be done through interviews where the researcher seeks answers to a set of questions through interviews. This method collects data in a structured way however the output relies on the capability of the interviewer [18].

For this research, Interviews were chosen to be conducted. This tool combines a pre-determined set of open questions with the opportunity for the interviewer to explore particular themes or responses further [19]. The primary data collected through semi-structural interviews done with six multichannel companies in Lebanon. The information gathered is classified into themes where the answers to them came from indirect questions in order to get credible information. The participants were managers mainly from both the IT and Marketing departments. However, this research study is an inductive one which purpose is to identify what is really going on in the Lebanese online market. Reference [20] shows that inductive research help to have a close understanding of the research context and it is done through the collection of qualitative data. Researchers mostly use the inductive approach in qualitative data and it opens the doors for many methods to be used in data collecting to create new views of phenomena [17].

The study will provide a view of the online shopping trend in Lebanon and the governmental challenges that the online retail is facing in Lebanon.

Throughout the literature review, we used the mono-qualitative approach to answer the research key questions. The interpretivist philosophy is applied in this research since it based on the naturalistic approach of data collection which is in this case through interviews [17]. 
The main limitations of the study would be the small size of the interview sample and whether different data would have emerged from different selection of managers and owners. Time constraints meant that it was not possible to conduct many more interviews, but it has to be acknowledged that insights could be lost and a full picture of the management of the company not obtained. A further limitation might be that customers were not interviewed, and their voice is not represented. Our focus was on management and hence we concentrated on those people who were formally engaged in the managing of the company rather than those subject to management. Finally, the methods used were mainly interviews; there was no in-depth ethnography to provide triangulation, or to confirm factual evidence.

\section{References}

[1] Yoldas, S. (2011). A research about buying behaviours of online customers. The Business School.

[2] Khanna, P., \& Sampat, B. (2015). Factors influencing online shopping during diwali festival 2014: Case study of flipkart and amazon. Journal of International Technology and Information Management, 24(2), 65.

[3] Mirmiran, F., \& Shams, A. (2014). The study of differences between e-commerce impacts on developed countries and developing countries; Case study: USA and Iran. New Marketing Research Journal, Special Issue, 79-100.

[4] Haddad, M., \& Kleiner, B. (2016). Consumer goods industry: Challenges within the online marketplace. Culture \& Religion Review Journal, 2016(4), 16-26.

[5] Korper, S., \& Ellis, J. (2001). Setting the vision: The e-commerce book, building the e-empire. San Diego: Academic Press.

[6] Mulpuru, S., Harteveldt, H. H., \& Roberge, D. (2011). Five retail ecommerce trends to watch in 2011. Reproduction, $x(y)$, 1-8. Forrester Research.

[7] Burr, L. C., Patterson, R. A., Rolland, E., \& Ward, K. F. (2007). Integration of E-CRM in healthcare services: A framework for analysis. International Journal of E-Business Research, 3(2), 1.

[8] Mathwick, C. (2002). Understanding the online consumer: A typology of online relational norms and behavior. Journal of Interactive Marketing, 16(1), 40-55.

[9] Langnau, L. (2002). Overcoming the barriers to e-commerce. Material Handling Management, 57(2), 41.

[10] Forsythe, S. \& Shi, B. (2003) Consumer patronage and risk perceptions in internet shopping. Journal of Business Research, 56(11), 867-875.

[11] Tamimi, N. Rajan, M. \& Sebastianelli, R. (2003), The state of online retailing. Internet Research, 13(3), pp 146-155. MBC UP Ltd.

[12] Sultan, M. U., \& Uddin, M. N. (2011). Consumers' Attitude towards online shopping: Factors influencing Gotland consumers to shop online.

[13] Lupu, S., Mual, M., \& Stiphout, M. (2016) Ecommerce Payment Report. The PAYPERS BV.

[14] Smith, E. R. (2000). E-loyalty: How to keep customers coming back to your website. Library Journal, 125(18), 94.

[15] Hitchcock, G., \& Hughes, D. (1995) Research and teacher, a qualitative introduction to school-based research. London: Routledge.

[16] Yin, R. (2003). Case Study Research, Design and Methods. London: Sage Publications.

[17] Easterby-Smith, M., Thorpe, R., \& Lowe, A. (2008). Management Research. London: SAGE.

[18] Kothari, C. R. (2004). Research Methodology: Methods and Techniques. Daryaganj: New Age International.

[19] Saunders, M., Lewis, P., \& Thornhill, A. (2012). Research Methods for Business Students. New York: Harlow, England: Pearson. 
[20] Saunders, M., Lewis, P., Thornhill, A., \& Wilson, J. (2009). Business Research Methods. London: Prentice Hall.

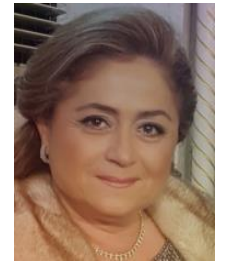

Najjar Dora was born in Lebanon in 1962. She got the PhD in management in Education University of Birmingham, UK (2009); the MBA with emphasis on Management University of Balamand, Lebanon (2003); the BS in Computer Science Beirut University College, Lebanon (1985). She worked as a school principal at Lady of Balamand High School from 2007 till 2013, she is an assistant professor at the University of Balamand from 2013 till now.

Dr. Najjar is a member of the Academy of Management, publication: Managerial Motivational Practices and Motivational Differences between Blue-and White-Collar Employees: Application of Maslow's Theory, IJIMT 2017 Vol.8(2): 81-84 ISSN: 2010-0248 doi: 10.18178/ijimt.2017.8.2.707

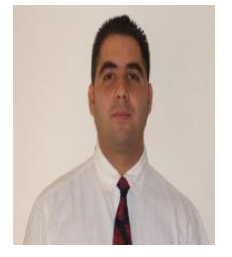

Shikhani Miguel was born in Venezuela in 1982. He got the MBA University of Balamand, Lebanon (2017); the MS Network Engineer University of Balamand, Lebanon (2007), the BS Computer Engineer University of Balamand, Lebanon (2005).

His working experience started as a developer at Libancosource Koura, Lebanon. In 2008 he got hired as a network engineer at the University of Balamand till present in Koura, Lebanon.

Mr. Shikhani is enrolled in the "Order of Engineers \& Architects" in Tripoli, Lebanon since 2013.

Maroun Jad was born in Lebanon in 1987. He got the MBA University of Balamand Koura, Lebanon 2017, Microsoft Certified IT Professional (MCITP) American Lebanese Language Center Jounieh, Lebanon 2012, Cisco Certified Network Associate (CCNA) American Lebanese Language Center Jounieh, Lebanon 2010, BS Information Technology University of Holy Spirit Kaslik, Lebanon 2010.

His working experience started as an IT officer on 2010 till 2012 at OTV Television Mkalles, Lebanon. In 2012 got hired as a Head of IT at Municipality of Jounieh, Lebanon. 